\title{
New Media Use in Brazil: Digital Inclusion or Digital Divide?
}

\section{Sueila Pedrozo, University of Turku, Finland}

\begin{abstract}
The emergence of information and communication technologies (ICTs) and, more recently, social network sites and online games brought profound changes to societies and people, particularly to young people. The new media changed communication, interaction, and leisure and provided a locus for identity development and group participation. Although the full impact of digital media on people and society is not yet known, there are already positive as well as negative concerns but new socialities and peer cultures may emerge. In Brazil, mobile phones became the main technology of connectivity, were rapidly adopted and reached all social classes as an example of democratic inclusion; however, the internet still lags behind as a result of socioeconomic, educational, and demographic inequalities that still prevail, cause the digital exclusion and place the Brazilian population at an unfavorable position. More public policies can convert the internet into a tool of citizenship so that the low-income people, especially the young, can benefit from it and become participants in the digital age. Future research should address these issues.
\end{abstract}

Keywords: mobile phone; internet; social network; inequality, digital divide; youth 
The focus of this article is the emergence of information and communication technologies (ICTs) in Brazil, stressing the adoption and popularity of mobile phones, the slower development of the internet and, more recently, the social network sites. Global transformations have continually pushed the country towards more advanced development, but its conditions are aggravated by extreme and prevailing contrasts - social, economic (income and wealth distribution) and educational which permeate the social fabric leading to digital exclusion and placing its population, the young in particular, at a disadvantage (Author 2011). However, it is important to discuss the new media as a growing social and cultural phenomenon within the Brazilian context, and how it pervades people's daily lives, young people inclusive, despite the so many unfavorable circumstances, especially in regard to education.

\section{Emergence of New Media}

During the 1990s, the plurality of new media and digital cultures [material practices of appropriation] became the centre of the debates; new media were not "out there" anymore but, instead, "here and amongst us" (Boomen, Lammes \& Lehmann, 2009, pp.8-9). As an extraordinary social phenomenon (Cooper, 2002) and above all a cultural one (Suoranta, 2003), new media are consumed in private and public spheres, integrated in modern societies, "crucially embedded in the structures and dynamics of contemporary consumer culture" (Silverstone \& Hirsch, 1994, p.2) and in the regular production and reproduction of human social patterns (Lefebvre, 1971). Craig Watkins (2009, pp.160-161) argues that "we have evolved from a culture of instant gratification to one of constant gratification. In many ways, the social - and mobile - media lifestyle represents a new cultural ethos and a profound shift in how we consume media". On the other hand, new media neither conform to a standard nor radically change lifestyles; instead, it fit in with them (Lie \& Sørensen, 1996). As Harper (2003, p.196) argues, "society makes the technology fits its needs".

Mobile phones and the internet have changed the notion of time and space (Neumayer, Raffl \& Bichler, 2010), became key ways of communication, interaction and leisure; the former reshaped earlier forms of communication instead of replacing them (Ling \& Horst, 2011) and the latter led to the emergence of different social networks (Näsi, Räsänen \& Lehdonvirta, 2011) such as MySpace, YouTube, Facebook, online games and others, and shaped societies with positive as well as negative outcomes - inequalities and educational gaps (Neumayer, 
Raffl \& Bichler). New media have also changed the face of education but numerous disparities concerning [ICT] infrastructure, technology access, and computer literacy still prevail within and among countries (Ottestad \& Quale, 2009). As Neumayer, Raffl and Bichler (p.46) remarked, contemporary societies are based on "many contradictions...for example, inclusion and exclusion". But, undoubtedly, digital media are changing the nature of people's social relationships and social network sites act as 'conduits' for connections and information (Baym, 2010). They are also "technologies of convergence" since they build upon personal and interpersonal potential for interaction which will lead to a merge of social practices and spaces (Papacharissi, 2011, pp. 304-310). Therefore, individual domains of sociality are not "restricted" but "reframed" and new forms of sociality may eventually develop - "mobile and flexible socialities" (Papacharissi, pp. 306-309).

The social impact of online networks on people, particularly on young people and on society, has been drawing the attention of specialists from different sectors of society; as Livingstone (2008) remarks, more optimistic views emphasize "new opportunities for community engagement, self-expression, sociabilities and new literacy skills", for example. On the other hand, more critical perspectives argue about lack of privacy and self-centeredness. There are also concerns regarding young people's production of creative material that will create a new local and global peer culture, but that will also oppose consumers' control by producers - as conventionally seen (pp. 394-395). Even if negative or positive outcomes are not yet known, social networking sites should be regarded as important social and cultural contexts which seem to provide young people and emerging adults with new places for friendship, communication, and leisure (Ito et al. 2009), for group participation and engagement in processes of identity construction ((Lehdonvirta \& Räsänen, 2011; Manago, A.M., Graham, M.B., Greenfield, P.M., \& Salimkhan, G., 2008), and for being in charge of one's individuality, lifestyle, and connectedness (Livingstone, 2008). The study of young people and MySpace conducted by Manago et al., for example, concluded that apparently young people's online world works as an elaborated continuum of their offline world; thus, performances and roles have endless opportunities in the online setting. There is, then, an interrelationship between online and offline worlds (Waechter, N., Subrahmanyam, K. Reich, S.M., \& Espinoza, G. 2010). 
The emergence of new patterns of socialization and identification break away from traditional links - family, communities, work, and allow today's youth to construct a reflexive project of the self (Bocock, 2001; Giddens, 1991). This is especially true when young people are the consumers of technology, as they enthusiastically adopt, shape and appropriate new media in their different forms (Castells et al., 2006; Horst \& Wallis, 2011; Ito et al., 2009; Ling, 2004), and their lives are mediated by ICTs which add and change existing leisure and consumption alternatives and practices (Livingstone, 2003). As Paul Willis (2000) argued:

Most of the ways in which we make meanings, most of our communications to other people, are not directly human and expressive, but interactions in one way or another worked through commodities and commodity relations: TV, radio, film, magazines, music, commercial dance, style, fashion, [and] commercial leisure venues. These are major realignments. (p. 48)

On the other hand, the way young people use technologies and the outcomes of their use depend upon social, economic and cultural frameworks; for example, parents' income and education are important factors when media-related goods are concerned, as they set limits on young people's patterns of use and socio-economic resources (Livingstone, 2003; Peter \& Valkenburg, 2006) thus, contributing to several possibilities for social distinction or exclusion (Bourdieu, 1984; Murdock, Hartmann \& Gray, 1992).

Despite possible restrictions that may occur, online social network sites have become a common destination for young people as well as young adults; in the USA from 2005 on, in the UK and across Europe in 2006 (Boyd, 2008; Livingstone, 2008), and in the rest of the world. In Brazil, Facebook is ahead of Orkut as the leading social network in the market with an increase of $192 \%$ in the past year, followed by Windows Live Profile and Twitter (comScore 2012) ${ }^{1}$. The way Brazilians appropriated these sites among others and, particularly Fotolog and Blogs, appears to have relation to users' needs for spaces of interaction and self-expression as well as for connecting and maintaining values on the internet (Recuero, 2008 a, 2008 b). As Horst (2011) argued "sociality has always been a key dimension of Brazil's engagement with the internet and new media" (p. 450).

\footnotetext{
${ }^{1}$ ComScore (January 17, 2012).

http://www.comscore.com/Press_Events/Press_Releases/2012/1/Facebook_Blasts_into_Top_Position_in_Brazil ian_Social_Networking_Market
} 


\section{New Media and the Digital Divide}

Political and public debates in the 1990s have focused their attention on whether new information and communication technologies would reduce the digital divide in terms of access and social inequalities. In fact, information and communication technologies' (ICTs) development, diffusion and adoption have fostered economic growth in countries around the world, although many countries remain uneven in all aspects and that unevenness becomes most evident particularly in current cities (Graham, 2002). Historically, any process of technical change has unequally benefited people in all places in a framework of social inequality, since sectors of society remained on the fringes of technological progress (Miles \& Gershuny, 1987; Silveira, 2003). Actually, old [social] structures are reinforced (Suoranta, 2003).

A number of studies (Fortunati, 2006; Norris, 2001; Räsänen, 2006) have argued that the digital divide is an indication of serious and more critical divides - social, economic, educational, and developmental - and "adds a fundamental cleavage to existing sources of inequality in a complex interaction" (Castells 2001, p. 247), as seen in poor countries where deprivation, illiteracy and basic needs as food, healthcare, housing and well-being are unattended. These factors create barriers and account for differences in internet access and use in developing countries and within disadvantaged groups in developed countries (Neumayer, Raffl \& Bichler, 2010; Newman, Biedrzycki \& Baum, 2010; Van Dijk \& Hacker, 2003).

The digital divide has been defined as the gap between have and have-nots, or the info-rich and info-poor in terms of access to new forms of information technologies (Castells, 2001; Haddon, 2004; Livingstone, 2003; Van Dijk, 2006; Wyatt, Henwood, Miller, \& Senker, 2000); as the unequal access to new media based on race, level of income, social position, education, age, employment, gender and organization of household in different regions of the world; between and within countries (Castells, 2001; Chen, Boase, \& Wellman, 2002; Lehdonvirta \& Räsänen, 2011; Mossberger, 2003; Selwyn, 2004; Servon, 2002). Hargittai (2002) has pointed to the importance of skill as a 'second level digital divide'; the main issue is not just technology access but digital literacy (Palfrey \& Gasser, 2008) - amount of use, familiarity with internet terminology and search mechanisms, evaluation of quality of information and social cooperation (DiMaggio, Hargittai, Neuman, \& Robinson, 2001; Van 
Dijk, 1999). Lack of computer literacy, cultural and economic factors affect disadvantaged youth in a more radical way, and may restrict even more their chances to participate in the increasingly demanding and globalized labor markets (Author, 2007).

It is also claimed that the digital divide is only binary (Warschauer, 2004) but, actually, there are several digital divides or a set of interconnected social, economic, political and technological issues besides physical and human resources and relationships (Gunkel, 2003; Van Dijk, 2005; Warschauer). This is an indication that technologies aggravate existing inequalities within socio-economic structures, promoting social differentiation (Lievrouw, 2001; Räsänen, 2006; Servon, 2002). The argument is considered technologically determinist and based on the notion that the use of technologies can bring certain applications and results (Bure, 2005). As a matter of fact, successful innovations are incorporated into society and soon start to change it; according to this view it is considered a technological revolution with significant social outcomes (Ling, 2004; Warschauer; Wyatt et al., 2000). To a certain extent people adopt technological innovations and assume they will function as predicted; technological determinism adapts to a significant number of people's experiences but with no room for one's choice and/or involvement (Henwood, Wyatt, Miller \& Senker, 2000).

In a second perspective, technology is considered neutral and does not question its origins except the way people use technical devices, and make individual or group choices. As a neutral tool emphasizing choice, it opposes the former view for acknowledging its social outcomes. The fundamental nature of this perspective, inspired by Bourdieu's work, is the production of social and cultural meanings, which are attributed to technological devices through consumption or use. A third view, called constructivism, regards technologies as artifacts made by people, which shape political, economic and cultural practices. They are constituted by different social groups, whereas for technological determinism social change comes as a result of technological change (Henwood et al., p. 8-12). According to Light's vision (2001) "technology is not a neutral tool with universal effects, but rather a medium with consequences that are significantly shaped by the historical, social, and cultural context of its use" (p. 711).

Castells (2001) argued that the importance of the internet in social, economic, and political areas is equivalent to marginality for people without, with little access, or unable to use new 
media adequately (p. 247). The way the internet is being diffused in most countries, benefiting the most educated people to the detriment of less-educated ones contributes to cause a deeper digital divide (p. 262). Although paths to bridge the digital exclusion are complex and depend on each country's social, political and economic contexts, the potential of media technologies should not be underrated as it is an important opening to informational, socio-economic, and cultural development (Chen et al., 2002); therefore, it is worth considering anything that might open possibilities (Thomas \& Wyatt, 2000). Alternative steps for new media implementation should focus more on local necessities of each country, since the current vision sees digital inclusion as inserted within homogenized global information society and economy (Avgerou \& Madon, p.8-10).

While the debate on the digital divide usually concentrates on the gap in internet access and use, for many people mobile phones have become one of the main technologies of connectivity (Fortunati \& Manganelli, 2002). From luxury to "citizenship commodity" (Fortunati, 2002, p. 526), a shift from a technology of a privileged few to a fundamentally mainstream technology (Castells, Fernandez-Ardevol \& Qiu, 2006), mobile phones confirmed the power of social inclusion and construction of citizenship. They became a tool of democratization capable of broadening access to communication (Fortunati, 2003). As Ling and Horst (2011) remark, "the mobile phone has quietly provided people at the bottom of the income pyramid access to electronically mediated communication; often for the first time."

The transformation of communication technologies in general, and mobiles phones in particular, has been considered one of the most conspicuous social changes to happen over the last decade, changing social relations and the self (Gergen, 2003; Sorj, 2003; Teather, 2000). In Italy as well as in India or Brazil, mobile phones were at first regarded as a luxury and adopted by upper classes, then widely spread across all social classes and, nowadays, millions of people use mobile phone technology (Fortunati, 2006; Hossain, Kathuria \& Islam, 2010; Schwittay, 2011). In Brazil this phenomenon happened when prices declined and mobile phones became the medium of communication for low income people; in the African continent, mobile phones also spread extraordinarily fast; in 2000, one in 50 Africans had access to a mobile while in 2008 the ratio was one in three (De Bruijn, Nyamnjoh, \& Brinkman, 2009, p.11). China, alone, has the largest world mobile population of 547 million 
(Guo \& Wu, 2009, p.34) but in terms of world population $61.1 \%$ used mobile phones in 2009, mainly driven by its use in the BRIC economies - Brazil, Russia, India and China (Baym, 2010 p.19).

\section{ICT in Brazil}

Brazil is currently the fifth largest mobile phone market in the world but the largest in Latin America (Castells et al., 2006). Mobile phones were introduced in 1990 but the adoption rate rapidly increased after 1992, despite socioeconomic inequalities. The explanation for the fast diffusion was the lack of landline supply and long waiting lists, due to major deficit in investments and public sector inefficiency. In 1998, when the Brazilian telecommunications sector was privatized, mobile phones' diffusion hugely intensified and increased even more when providers introduced pre-paid cards. It proved to be an example of democratization in terms of inclusion, particularly empowering low-income people and those working in the informal labor sector ${ }^{2}$ so they could communicate without time and/or place restrictions despite the high costs of pre-paid mobiles. Data from Agência Brasil (2011) points to a significant growth: the number of mobile phones (202.94 million) exceeds the number of inhabitants (190.3 million).

On the other hand the internet still lags behind as a result of socioeconomic, educational, and demographic inequalities that still prevail, cause the digital exclusion and place the Brazilian youth population, in particular, at an unfavorable position. It involves two major factors: the high costs of computers and connections and the lack of familiarity with technology. Usually, the highest rates of digital exclusion are found in low income classes, since there is a strong relationship between digital exclusion with other kinds of exclusion (Sorj, 2003). However, as Santos (2009, p.46) explained, a large number of people who earn between three and five minimum wages (respectively R\$ 1245,00 = US\$ 754.50 and R\$2075,00 = US\$ 1257.60) became internet users in 2008 as a result of computer price reductions, as well as funding provided by public policies. All these actions further contributed to a significant growth of internet access, as pioneering initiatives started back in the 1990s by the Center for Digital Inclusion $^{3}$ followed by federal government programs in the $2000 \mathrm{~s}$, as the project Computador

\footnotetext{
${ }^{2}$ Self-employed or employed without formal contract

${ }^{3} \mathrm{CDI}$ is a global NGO based in Brazil. Retrieved from http://www.cdi.org.br/
} 
para Todos (Computer for all $)^{4}$. But despite numerous efforts and policies from individual municipalities, community-based organizations, non-profit organizations and private companies to reduce the digital exclusion, "access does not guarantee use" as Ono and Zavodny (2007, p. 1151) pointed out, since people who are nonusers might possibly stay behind any societal change. More investments in public policies of inclusion are demanded because although socioeconomic, educational and demographic inequalities are critical, the internet can be converted into a tool of citizenship so that the low-income people, especially the young, can benefit from it and become participants in the digital age.

The National Household Sample Survey (IBGE, 2009) showed that despite the increase of internet access in recent years, a critical digital divide still exists within the country; for example, in the southeastern region the access ${ }^{5}$ to the internet was around $48.1 \%$ compared with $26.2 \%$ in 2005 , while in the northeastern area was just about $30.2 \%$ compared with $11.9 \%$ in 2005 . The sample ${ }^{6}$ included 58.6 million homes; almost 35\% (20.3 million people) had personal computers, $27.4 \%$ (16 million) had access to the internet, and 104.7 million people (10 years of age on) or $65.2 \%$ did not use the internet in the three months previous to the survey. There were three main reasons for not using the internet: For $32.8 \%$ of the people it was not necessary or they did not want; $31.6 \%$ did not know how to use it and $32.8 \%$ did not have a computer. The results have indicated that younger groups - 10-14 years old (58.8\%), 15-17 years old (71.1\%) and 18 or 19 years old (68.7\%) accessed the internet more than other age groups, and users were more educated than those who did not access. In addition, it was also reported that women's internet access growth (22.9\%) surpassed men's $(20 \%)^{7}$.

The survey has also pointed to household income, education and age as socio-demographic factors with the strongest effect on ICT ownership and use. As more educated people $(74.5 \%$ and $15+$ years of formal education) have internet access, this is only granted to $35.6 \%$ of the less educated ones (up to 10 years of education). Broadband access and use also increases

\footnotetext{
${ }^{4}$ Computador para Todos is a federal government project in partnership with private sectors. http://www.governoeletronico.gov.br/acoes-e-projetos/inclusao-digital/programa-computador-para-todos.

${ }^{5}$ Internet access is here defined as the proportion of people who were connected to the network at least once in the three months previous to the survey.

${ }^{6} \mathrm{http} / / / \mathrm{www}$. ibge.gov.br/home/estatistica/populacao/trabalhoerendimento/pnad2009/comentarios2009.pdf

${ }^{7}$ http://www.ibge.gov.br/home/estatistica/populacao/trabalhoerendimento/pnad2009/pnad_sintese_2009.pdf
} 
with wage range as Olinto and Fragoso (2010/2011, p. 7) indicated. In rural areas, the main problems of the digital inclusion are the lack of network availability and the high costs of connections; thus increasing the use of LAN houses (similar to cybercafés) - a trend in Brazil cutting across all social classes, although its use is mainly associated to people's age - the young and the low-income (Santos, 2009, p. 45). As suggested by Wijers (2010), if young people's level of higher education (in this case any level of education exceeding primary school) were upgraded in a country, this could result in promising solutions to the digital divide.

Data analysis of the 2007 Latinobarómetro report pointed to age and education as key factors in the internet use in Brazil; race, labor, gender and income did not affect the chances to access in a regular way (Schlegel, 2009). According to Schlegel, internet access seems to have a strong correlation to social status, especially if access distribution is compared along with schooling (p.137-142). As the author discussed:

The fact that schooling is such a strong factor may indicate that the fight against digital exclusion, in Brazil, must be [done] through educational inclusion, broadening the access to quality education. But a wider look at the results suggests that the predominance of what is called cultural capital, basically information and knowledge, is determinant of internet regular use. (p.154)

Digital inclusion is also strongly related to the transformation of schools - teachers' training, computers' educational use and its integration to the process of teaching and learning (Silveira, 2003). As Castells (2001, p. 259) notes, private schools are differentiated from public schools in terms of race, social class and technology resources; in Brazil, education provided for the poor is characterized by heterogeneity - contrasts are visible in geographical regions, educational systems, quality, material and human resources, thus accentuating the inclusion/exclusion mechanism (Schwartzman \& Reis, 2005). Digital exclusion, in turn, also prevents the effectiveness of policies for the reduction of social exclusion, as activities related to government and economic spheres and a large amount of cultural production have shifted to the internet. The worsening of technological inequalities in information society as a result of historical, economic and political factors is, nevertheless, reinforced by people's exclusion from technological access and its development (Silveira, 2003, pp. 18-33). So, the information society should add a "pro-poor approach" in order to decrease the high levels of 
social exclusion and disparities, particularly in Latin America, known for its low levels of human and economic development (Barja \& Gigler, 2007, p.15). As Silveira (2003, pp. 3031) observed, digital inclusion in the information society is meant to ensure the right to interactive communication.

\section{Concluding Remarks and Discussion}

As Craig Watkins (2009, pp.160-161) remarked "we have evolved from a culture of instant gratification to one of constant gratification. In many ways, the social - and mobile - media lifestyle represents a new cultural ethos and a profound shift in how we consume media".

Digital media and online social networks became part of young people's daily lives and the locus of the reflexive project of the self (Giddens, 1991), new identities and lifestyles. Digital media brought new ways of communicating, interacting, new forms of leisure and selfexpressing; its adoption and popularity gave rise to social networks, and people's social relationships have changed (Baym, 2010). The importance of social network sites lies on the fact that they are important contexts, social and cultural for "communication, friendship and play" (Ito et al., 2009, p.1), "socialization and identification experiences" for today's youth (Lehdonvirta \& Räsänen, 2011, p.91), engagement in processes of identity development (Manago et al., 2008) and as a way of being in charge of one's individuality, lifestyle and social connections (Livingstone, 2008). However, as the outcomes of such a major social change are not known yet, there are concerns, both positive and negative, regarding the implications on people. New peer cultures may develop as ICTs mediate more and more young people's lives creating new consumption patterns and social interaction. New socialities may emerge - "mobile and flexible" (Papacharissi, 2011, pp. 306-309).

The emergence of ICTs brought economic growth and development for many countries, but brought the digital divide as well. In Brazil, there was a democratization effect with the adoption of mobile phones reaching all social classes but the internet still lags behind. No doubt there is a correlation between digital exclusion and other forms of inequalities - social, economic, educational, and demographic. Technology access is just the first step to digital inclusion but digital literacy is even more important and has to follow it; the full inclusion for all depend not only on public policies but mainly on quality education and teachers' training, to enable underprivileged youth to learn and use ICT resources and potential. 
Although there is a growing academic interest in research on mobile phones and new media in general, there is a considerable lack of research on the social and cultural aspects of new media in Brazil; for example, mobile phones, the internet, social media, and its practices. Further studies, for instance, on the impact of new technologies on young people, particularly social networks, focusing on social and cultural aspects and their relation to existing structures should be conducted, since there is a huge gap in the current academic literature. There are many studies on youth violence in Brazil, but more research on the other dimensions of youth behavior is needed. Research is equally important to point out the ways low-income sectors of society appropriate new technologies, either by tracing the advances of the digital inclusion in Brazil and in the developing world as well, or by looking into the creative forms new media is introduced in those people's lives. 


\section{References}

Agência Brasil (2011, January 1). Retrieved March10, 2012 from http://agenciabrasil.ebc.com.br/node/641696

Avgerou, C., \& Madon, S. (2005). Information society and the digital divide problem in developing countries. In J. Berleur \& C. Avgeroui (Eds.), Perspectives and policies on ICT in society (pp.205-218). New York, NY: Springer. Retrieved February 15, 2012 from

http://eprints.1se.ac.uk/2576/1/Information_society_and_the_digital_divide_problem _in_developing_countries_\%28LSERO\%29.pdf

Barja, G., \& Gigler, B.S. (2007). The concept of information poverty and how to measure it in the Latin American context. In H. Galperín \& J. Mariscal (Eds.), Digital poverty: Latin America and Caribbean perspectives (pp.11-28). Ottawa, CA: IDCR.

Baym, N. K. (2010). Personal connections in the digital age. Cambridge, UK: Polity Press. Bocock, R. (2001). Consumption. (4 ${ }^{\text {th }}$ ed). London: Routledge.

Boomen, M.V.D., Lammes, S., \& Lehmann, A.S. (2009). Introduction: From the virtual to matters of fact and concern. In M.V.D. Boomen, S. Lammes, A.S. Lehmann, J. Raessens, \& M.T. Schäfer (Eds.), Digital material: Tracing new media in everyday life and technology (pp.7-17). Amsterdam: Amsterdam University Press.

Bourdieu, P. (1984). Distinction: A social critique of the judgement of taste. Cambridge, MA: Harvard University Press.

Boyd, D. (2008). Why Youth (Heart) Social Network Sites: The Role of Networked Publics in Teenage Social Life. MacArthur Foundation in Digital Learning. In D. Buckingham (Ed.), Youth, Identity, and Digital Media Volume (pp.119-142). Cambridge, MA: MIT Press.

Bure, C. (2005). Digital inclusion without social inclusion: The consumption of information and communication technologies (ICTs) within homeless subculture in Scotland. The Journal of Community Informatics, 1, (2), 116-133. Retrieved November 5, 2011 from http://ci-journal.net/index.php/ciej/issue/view/14

Castells, M. (2001). The Internet galaxy: Reflections on the Internet, business and society. Oxford, UK: Oxford University Press.

Castells, M., Fernandez-Ardevol, M. \& Qiu, J. L. (2006). Mobile communication and society: A global perspective. Cambridge, MA: MIT Press. 
Chen, W., Boase, J., \& Wellman, B. (2002). The global villagers: Comparing internet users and uses around the world. In B. Wellman \& C. Haythornthwaite (Eds.), The internet in everyday life (pp.74-113). Oxford, UK: Blackwell.

Cooper, G. (2002). The mutable mobile: Social theory in the wireless world. In B. Brown, N. Green, \& R. Harper (Eds.), Wireless world: Social and interactional aspects of the mobile age (pp.19-31). London: Springer-Verlag.

De Bruijn, M., Nyamnjoh, F., \& Brinkman, I. (2009). Introduction: Mobile communications and new social spaces. In M. De Bruijn, Nyamnjoh, F., \& I. Brinkman (Eds.), Mobile phones: The new talking drums of everyday Africa (pp. 11-22). Cameroon: Langaa.

DiMaggio, P., Hargittai, E., Neuman, R. W., \& Robinson, J. P. (2001). Social implications of the internet. Annual Review of Sociology 27, 307-336. doi: 10.1146/annurev.soc.27.1.307

Fortunati, L. (2002). The mobile phone: Towards new categories and social relations. Information, Communication and Society 5 (4), 513-528. doi: $10.1080 / 13691180208538803$

Fortunati, L., \& Manganelli, A. M. (2002). A review of the literature on ICT in Italy. SIGIS Report. METIS Centre: Italy.

Fortunati, L. (2003). The mobile phone and democracy: An ambivalent relationship. In K. Nyíri (Ed.), Mobile democracy: Essays on society, self and politics (pp.239-258). Bielefeld, DE: Passagen Verlag.

Fortunati, L. (2006). User design and the democratization of the mobile phone. First Monday, 7, Special issue. Retrieved October 6, 2011 from http://firstmonday.org/htbin/cgiwrap/bin/ojs/index.php/fm/article/view/1615/1530

Gergen, K. J. (2003). Self and the community in the floating worlds. In K. Nyíri (Ed.), Mobile democracy: Essays on society, self and politics (pp.103-114). Bielefeld, DE: Passagen Verlag.

Giddens, A. (1991). Modernity and self-identity: Self and society in late modernity. Stanford, CA: Stanford University Press.

Graham, S. (2002). Bridging urban digital divides? Urban polarisation and information and communication technologies (ICTs). Urban Studies 39 (1), 33-56. doi: 10.1080/00420980220099050. 
Gunkel, D. J. (2003). Second thoughts: Toward a critique of the digital divide. New Media and Society, 15 (4), 499-522. doi: 10.1177/146144480354003.

Guo, Z., \& Wu, M. (2009). Dancing thumbs: Mobile phone in contemporary China. In X. Zhang \& Y. Zheng (Eds.), China's information and communications technology revolution (pp. 34-51). Oxon, UK: Routledge.

Haddon, L. (2004). Information and communication technologies in everyday life: A concise introduction and research guide. Oxford, UK: Berg.

Hargittai, E. (2002). Second-level digital divide: Differences in people's online skills. First Monday 7 (4). Retrieved March 2, 2012 from http://firstmonday.org/htbin/cgiwrap/bin/ojs/index.php/fm/article/view/942/864

Harper, R. (2003). Are mobiles good or bad for society? In K. Nyíri (Ed.), Mobile democracy: essays on society, self and politics (pp. 185-214). Bielefeld, DE: Passagen Verlag.

Henwood, F., Wyatt, S., Miller, N., \& Senker, P. (2000). Critical perspectives on technologies, inequalities and the information society. In S. Wyatt, F. Henwood, N. Miller, \& P. Senker (Eds.), Technology and in/equality: Questioning the information society (pp.227-241). London: Routledge.

Horst, H.A. (2011). Free, social and inclusive: Appropriation and resistance of new media technologies in Brazil. International Journal of Communication 5, 437-462. Retrieved March 3, 2012 from http://ijoc.org/ojs/index.php/ijoc/article/view/699/531

Horst, H.A., \& Wallis, C. (2011). Special Section: New media in international contexts. Introduction. International Journal of Communication 5, 463-470. Retrieved March 3, 2012 from http://ijoc.org/ojs/index.php/ijoc/article/view/1092/533

Hossain, M., Kathuria, R., \& Islam, I. (2010). South Asian economic development ( $2^{\text {nd }}$ ed.). Oxon, UK: Routledge.

IBGE (2008). Brazilian Institute of Geography and Statistics. Retrieved January 7, 2012 from www.ibge.gov.br/estatistica/populacao/acessoainternet2008/internet.pdf

Ito, M., Baumer, S., Bittanti, M., Boyd, D., Cody, R., Herr-Stephenson, B. et al. (2009). Hanging out, messing around, and geeking out: Kids living and learning with new media. Cambridge, MA: MIT Press. 
Lehdonvirta, V., \& Räsänen, P. (2010). How do young people identify with online and offline peer groups? A comparison between UK, Spain and Japan. Journal of Youth Studies 14 (1), 1-18. doi: 10.1080/13676261.2010.506530

Lefebvre, H. (1971). Everyday life in the modern world. London: Allen Lane.

Lie, M., \& Sørensen, K.H. (1996). Making technology our own? Domesticating technology into everyday life. Oxford: Scandinavian University Press.

Lievrouw, L. A. (2001). New media and the 'pluralization of life-worlds'. New Media and Society 3 (1), 7-28. doi: 10.1177/1461444801003001002.

Light, J. (2001). Rethinking the digital divide. Harvard Educational Review 71 (4), 709-733. Ling, R. (2004). The mobile connection: The cell phone's impact on society. San Francisco, CA: Morgan Kaufmann.

Ling, R., \& Horst, H. A. (2011). Mobile communication in the global south. New Media \& Society 13 (3), 363-374. doi: 10.1177/1461444810393899

Livingstone, S. (2008). Taking risky opportunities in youthful content creation:teenagers' use of social networking sites for intimacy, privacy and self-expression. New Media \& Society 10 (3), 393-411. doi: 10.1177/1461444808089415

Livingstone, S. (2003). Young people and new media. London: Sage.

Manago, A.M., Graham, M.B., Greenfield, P.M., \& Salimkhan, G. (2008). Self-presentation and gender on MySpace. Journal of Applied Developmental Psychology 29 (6), 446458. doi: http://dx.doi.org/10.1016/j.appdev.2008.07.001

Miles, I., \& Gershuny, J. (1987). The social economics of information technology. In R. Finnegan, G. Salaman, \& K. Thompson (Eds.), Information technology social issues: A reader (pp.209-224). London: Hodder and Stoughton.

Mossberger, K. (2003). Virtual inequality: Beyond the digital divide. Washington, D.C.: Georgetown University Press.

Murdock, G., Hartmann, P., \& Gray, P. (1992). Contextualizing home computing: Resources and practices. In R. Silverstone \& E. Hirsch (Eds.), Consuming technologies: Media and information in domestic spaces (pp.146-160). London: Routledge.

Näsi, M., Räsänen, P., \& Lehdonvirta, V. (2011). Identification with online and offline communities: Understanding disparities in Finland. Technology in Society 33, 4-11. doi: http://dx.doi.org/10.1016/j.techsoc.2011.03.003

Neumayer, C., Raffl, C., \& Bichler, R.M. (2010). Politics and social software: Recommendations for inclusive ICTs. In D. Riha \& A.Maj (Eds.), Emerging 
practices in cyberculture and social networking (pp.41-62). Amsterdam: Editions Rodopi.

Newman, L. A., Biedrzycki, K., \& Baum, F. (2010). Digital technology access and use among socially and economically disadvantaged groups in South Australia. Journal of Community Informatics 6 (2). Retrieved September 15, 2011 from http://cijournal.net/index.php/ciej/issue/view/32

Norris, P. (2001). Digital divide: Civic engagement, information poverty, and the internet. Cambridge, NY: Cambridge University Press

Olinto, G., \& Fragoso, S. (2011). Internet use and community informatics in

Brazil: Speeding up or lagging behind? Community Informatics 7 (1-2), 1-14. Retrieved February 13, 2012 from http://ci-journal.net/index.php/ciej/article/view/835/725

Ono, H., \& Zavodny, M. (2007). Digital inequality: A five country comparison using microdata. Social Science Research, 36 (3), 1135-1155. doi: 10.1016/j.ssresearch.2006.09.001.

Ottestad, G., \& Quale, A. (2009). Trends in instructional ICT infrastructure. In Tj. Plomp, R. E. Anderson, N. Law \& A. Quale (Eds.), Cross-National Information and Communication Technology: Policies and Practices in Education (2 ${ }^{\text {nd }}$ ed.) (41-64). Charlotte, NC: Information Age Publishing.

Palfrey, J., \& Gasser, U. (2008). Born digital: Understanding the first generation of digital natives. New York, NY: Basic Books.

Papacharissi, Z. (2011). Conclusion: A networked self. In Z. Papacharissi (Ed.), A networked self: Identity, community and culture on social network sites, 304-318. New York, NY: Routledge.

Pedrozo, S. (2011). To be 'cool'or not to be 'cool': Young people's insights on consumption and social issues in Rio de Janeiro. Journal of Youth Studies, 14, (1), 109-123.

Peter, J., \& Valkenburg, P.M. (2006). Adolescents' internet use: Testing the 'disappearing digital divide' versus the 'emerging digital differentiation' approach. Poetics 34, $293-$ 305. doi:10.1016/j.poetic.2006.05.005.

Räsänen, P. (2006). Information society for all? Structural characteristics of internet use in 15 European countries. European Societies 8 (1), 59-81. doi: $10.1080 / 14616690500491423$.

Recuero, R. (2008). Redes sociais na internet [Social networks on the internet]. Porto Alegre: Editora Sulina. 
Recuero, R. (2008a). Information flows and social capital in Weblogs: A case study in the Brazilian blogosphere. In ACM Conference on Hypertext and Hypermedia 2008, Pittsburgh, Proceedings of Hypertext. Retrieved December 3, 2011 from http://pontomidia.com.br/raquel/ht08fp009recuerofinal.pdf

Recuero, R. (2008b). Appropriations of Fotolog as social network site: A Brazilian case study. In Internet Research Conference 9.0. Copenhagen. Proceedings of IR 9.0, 2008. Retrieved December 3, 2011 from http://pontomidia.com.br/raquel/aoir2007.pdf

Santos, Rogério Santanna dos (2009) Cresce o acesso às TICs, mas ainda é grande o desafio de democratizá-las a todos os brasileiros [ICT access grows but is a great challenge to democratize to all Brazilians]. Pesquisa sobre o uso das tecnologias da informação e da comunicação [Research on ICTs' use], pp. 45-48. Retrieved from July 14, 2011 from http://cgi.br/publicacoes/artigos/artigo58.htm.

Schlegel, R. (2009). Internauta Brasileiro: Perfil diferenciado, opiniões indiferenciadas [Brazilian internet user: Different profiles, similar opinions]. Revista de Sociologia e Politica 17 (34), 137-157. doi: 10.1590/S0104-44782009000300011

Schwittay, A. (2011). New media practices in India: Bridging past and future, markets and developments. International Journal of Communication 5, 349-379. Retrieved January 11, 2012 from http://ijoc.org/ojs/index.php/ijoc/article/view/702/528

Selwyn, N. (2004). Reconsidering political and popular understandings of the digital divide. New Media and Society 6 (3), 341-362. doi: 10.1177/1461444804042519.

Servon, L. J. (2002). Bridging the digital divide: Technology, community, and public policy. Malden, MA: Blackwell.

Silveira, S. A. (2003). Exclusão digital [Digital exclusion]. São Paulo: Fundação Editora Perseu Abramo.

Silverstone, R., \& Hirsch, E. (1994). Introduction. In: Silverstone, R. \& Hirsch, E. (Eds.), Consuming technologies: media and information in domestic spaces (pp.1-11). London: Routledge.

Sorj, B. (2003).Brasil@povo.com [Brazil@people.com]. Rio de Janeiro: Zahar.

Suoranta, J. (2003). The world divided in two: Digital divide information and communication technologies, and the 'youth question'. Journal for Critical Education Policy Studies 1 (2). Retrieved February 5, 2012 from http://www.jceps.com/index.php?pageID=article\&articleID=16 
Teather, D. (2000, October). Half of all Britons own mobile phones. The Guardian. Retrieved November 10, 2010 from http://www.guardian.co.uk/media/2000/oct/05/uknews

Thomas, G., \& Wyatt, S. (2000). Access is not the only problem: Using and controlling the internet. In S. Wyatt, F. Henwood, N. Miller \& P. Senker (Eds.), Technology and in/equality: Questioning the information society (pp.21-45). London: Routledge.

Van Dijk, J. (1999). The network society: Social aspects of new media. London: Sage.

Van Dijk, J., \& Hacker, K. (2003). The digital divide as a complex and dynamic phenomenon. The Information Society 19, 315-326. doi: $10.1080 / 01972240390227895$.

Van Dijk, J. (2005). The deepening divide: Inequality in the information society. London: Sage.

Van Dijk, J. (2006). Digital divide research, achievements and shortcomings. Poetics 34 (45), 221-235. doi: 10.1016/j.poetic.2006.05.004.

Waechter, N., Subrahmanyam, K. Reich, S.M., \& Espinoza, G. (2010). Youth connecting online: From chat rooms to social networking sites. In D. Riha \& A. Maj (Eds.), Emerging practices in cyberculture and social networking (pp.151-178). Amsterdam: Editions Rodopi.

Warschauer, M. (2004). Technology and social inclusion: Rethinking the digital divide. Cambridge, MA: MIT Press.

Watkins, S.C. (2009). The young and the digital. Boston, MA: Beacon Press.

Wijers, G. D. M. (2010). Determinants of the digital divide: A study on IT development in Cambodia. Technology in Society 32 (4), 336-341. doi: http://dx.doi.org/10.1016/j.techsoc.2010.10.011

Willis, P. (2000). The ethnographic imagination. Cambridge, UK: Polity Press.

Wilska, T-A., \& Pedrozo, S. (2007). New technology and young people's consumer identities: A comparative study between Finland and Brazil. Young, 15, (4), 343368.

Wyatt, S., Henwood, F., Miller, N., \& Senker, P. (2000). Technology and in/equality: Questioning the information society. London: Routledge. 